\title{
PENGARUH HARGA, KEMUDAHAN, DAN KEPERCAYAAN TERHADAP KEPUTUSAN PEMBELIAN TIKET PESAWAT MELALUI MOBILE APPLICATION GARUDA INDONESIA
}

\author{
Nur Annisa Fitri ${ }^{1}$, IGPB. Sasrawan Mananda ${ }^{2}$, Putu Agus Wikanatha Sagita ${ }^{3}$ \\ ${ }^{1}$ Email: nurannisafitri.ipw2014@yahoo.com \\ Program Studi Sarjana Industri Perjalanan Wisata, Fakultas Pariwisata, Universitas Udayana \\ ${ }^{2}$ Email: gusmananda@unud.ac.id \\ Program Studi Sarjana Industri Perjalanan Wisata, Fakultas Pariwisata, Universitas Udayana \\ 3Email: aguswika@unud.ac.id \\ Program Studi Sarjana Industri Perjalanan Wisata, Fakultas Pariwisata, Universitas Udayana
}

\begin{abstract}
The aim of this research is to find out if ratings and reviews were influenced by price, ease to use, and trusted in their purchasing decisions by domestic tourists through Garuda Indonesia mobile application user in DKI Jakarta. The selection of the sample using the method of purposive sampling total of 100 respondents. Data collection techniques used observation, interviews, questionnaires, and literature. The data analysis technique in this study is descriptive analysis, validity and reliability test, classic assumption test, hypothesis test, multiple linear analysis, correlation analysis, and coefficient of determination analysis using SPSS version 21.0 for windows. The result of this study indicate the effect of price, easy to use, and trust the decision to purchase airplane tickets by domestic tourists through Garuda Indonesia's mobile application in DKI Jakarta is very significantly simultaneous and partial effect with a value of $60,6 \%$. For price the result of value $t_{\text {count }}$ is 2.757 , easy to use 3.533 , and trust 3.958. The data collected through online questionnaires to the respondents who had purchased airline tickets for Garuda Indonesia mobile application.
\end{abstract}

Abstrak: Tujuan penelitian ini untuk mengetahui apakah rating dan review dipengaruhi oleh harga, kemudahan, dan kepercayaan dalam keputusan pembelian tiket pesawat oleh wisatawan domestik melalui mobile application Garuda Indonesia di DKI Jakarta. Pemilihan sampel pada penelitian ini menggunakan metode purposive sampling 100 responden. Teknik pengumpulan data yang digunakan yaitu observasi, wawancara, penyebaran kuesioner, studi dokumentasi, studi kepustakaan. Teknik analisis data dalam penelitian ini adalah analisis deskriptif, uji validitas dan reliabilitas, uji asumsi klasik, uji hipotesis, analisis linier berganda, analisis korelasi, dan analisis koefisien determinasi dengan menggunakan SPSS version 21.0 for windows. Hasil dari penelitian ini menunjukkan pengaruh harga, kemudahan, dan kepercayaan terhadap keputusan pembelian tiket pesawat oleh wisatawan domestik melalui mobile application Garuda Indonesia di DKI Jakarta dinyatakan berpengaruh signifikan secara simultan dan parsial dengan nilai sebesar 60,6\%. Variable harga memiliki nilai $t_{\text {hitung }} 2.757$, kemudahan sebesar 3.533, dan kepercayaan sebesar 3.958. Data penelitian ini diperoleh dari penyebaran kuesioner online kepada responden yang telah membeli tiket pesawat Garuda Indonesia melalui mobile application Garuda Indonesia.

Keywords: price, easy to use, trust, decision to buy, mobile application garuda indonesia. 


\section{PENDAHULUAN}

Industri pariwisata merupakan salah satu industri yang membutuhkan pertukaran informasi dengan cepat dan akurat, dimana para pelaku bisnisnya melakukan komunikasi dengan konsumenya melalui berbagai media informasi dalam memasarkan produknya dan membangun hubungan dengan konsumen dan pemasok. Informasi mempunyai peran yang sangat penting dalam melakukan perencanaan wisata karena dapat mempengaruhi pengambilan keputusan destinasi tujuan wisata dan perencanaan pembelian seperti akomodasi, transportasi, aktivitas, atraksi, makanan, dan lainnya (Hyde, 2008). Internet telah menjadi sebuah kebutuhan dalam pencarian informasi terkait perencanaan, pengambilan keputusan wisata dan segala keputusan pembelinya. Hal ini disebabkan internet telah menjadi sumber informasi utama yang memiliki tingkat interaktifitas dan kostumisasi tinggi sehingga dapat memberikan pengalaman sesuai dengan kebutuhan penggunanya (Herlina, 2013).

Internet memiliki peran penting untuk mengenalkan kita pada dunia maya. Kini di berbagai negara memasuki suatu era baru yang disebut era globalisasi. Era globalisasi merupakan suatu era di mana batas-batas geografi antarnegara tidak lagi menjadi hambatan dalam proses komunikasi dan interaksi antar individu. Internet di Indonesia saat ini sudah menjadi kebutuhan primer untuk pengguna dalam menjalanakan sejumlah aktivitas. Dengan semakin berkembangnya jumlah pengguna internet di Indonesia, mendorong terciptanya sejumlah kegiatan melalui jaringan online. Oleh karena itu, internet menjadi suatu kebutuhan mutlak yang dibutuhkan bagi konsumen atau pengguna (Ani, 2009).

Melalui pemasaran elektronik dan komunikasi internet, para pelaku bisnis mengoordinasikan berbagai aktivitas pemasaran yang berbeda seperti riset pemasaran, pengembangan produk, menginformasikan para konsumen tentang karakteristik produk, layanan konsumen, umpan balik konsumen dan sebagainya. Peluang penjualan menggunakan sistem elektronik dilirik oleh banyak perusahaan baik produsen produk maupun jasa salah satunya maskapai penerbangan. Asociacion para la Investigacion de Medios de Communicacion (AIMC) Spanyol menyebutkan bawa pembelian e-ticket maskapai menjadi produk paling laris beberapa tahun terakhir. Beberapa hal tersebut membutikan bahwa pasar perdagangan sistem elektronik melalui internet menjadi pasar bagi maskapai dunia tidak terkecuali di Indonesia.

Maskapai penerbangan di Indonesia sendiri menggunakan sistem penjualan tiket pesawat terbang yang tidak berbeda dari Negara lain. Sistem penjualan dibedakan menjadi penjualan tradisional atau manual yang mengharuskan pembeli bertatap muka langsung dengan petugas ticketing di kantor cabang maskapai atau agen perjalanan dan penjualan online yang tidak mengharuskan pembeli bertatap muka dengan petugas pertiketan melainkan menggunakan perangkat elektronik mereka yang terhubung dengan jaringan internet. Penjualan melalui online dapat dilakukan dengan cara membuka situs internet maskapai tertentu, aplikasi telepon pintar (smartphone) maskapai tertentu.

Salah satu maskapai pernerbangan yang menjadi pilihan wisatawan yaitu Garuda Indonesia. Garuda Indonesia adalah perusahaan jasa penerbangan milik Pemerintah Negara Republik Indonesia yang sudah berdiri sejak tanggal 4 Maret 1975. Perusahaan Garuda Indonesia memiliki kepercayaan serta integritas yang tinggi terhadap konsumenkonsumennya, serta perusahaan ini sudah berhasil meraih penghargaan sebagai maskapai penerbangan regional terbaik di dunia yang diberikan oleh Skytrax, dalam menjaga hubungan terhadap konsumen-konsumennya Garuda Indonesia senantiasa memberikan harga yang sesuai dengan fasilitas pelayanan serta selalu up to date dalam membuka jalurjalur rute penerbangan terbaru, baik rute penerbangan nasional maupun internasional.

Maskapai Garuda Indonesia mempunyai berbagai macam strategi pemasaran penjualan tiket pesawat yaitu secara online dan offline. Beragam strategi pemasaran penjualan tiket pesawat Garuda Indonesia secara online yaitu melalui website dan mobile application. Mobile application Garuda Indonesia merupakan aplikasi multiplatform yang dapat digunakan pada platform Android maupun iOs. Dari tampilan mobile application tersebut, terdapat jumlah pembelian tiket pesawat Garuda Indonesia melalui mobile application dari tahun 2015 sampai tahun 2017 mengalami peningkatan. Peningkatan tersebut dapat 
dinilai secara positif sebagai kemajuan penjualan tiket pesawat pada mobile aplikasi Garuda Indonesia. Kenaikan jumlah pembelian tiket pesawat Garuda Indonesia dikarenakan pola pemasaran yang baik dari Garuda Indonesia terkait penjualan melalui mobile application seperti pengenalan fitur dari platform smartphone Android dan iOs. Pengenalan mobile application kepada wisatawan Garuda Indonesia yang terkenal loyal terhadap perusahaan melalui Garuda Indonesia Online Travel Fair yang diadakan pertama kali tahun 2015 pada saat itu 1 (satu) periode Garuda Indonesia Online Travel Fair diadakan 3 (tiga) kali yang membuat mobile application Garuda Indonesia dikenal oleh wisatawan sehingga mengalami penjualan tiket pesawat yang meningkat akan tetapi mobile application Garuda Indonesia sendiri baru dirilis pada tahun 2015 maka dari itu rating maupun review pada mobile application Garuda Indonesia mengalami permasalahan.

Meningkatnya jumlah pembelian tiket pesawat melalui mobile application Garuda Indonesia yang tidak sejalan dengan rating dari mobile application tersebut mengalami permasalahan. Rating yang diberikan oleh wisatawan bermacam-macam, ada yang mengatakan sangat puas dengan sistem mobile application Garuda Indonesia adapun yang mengatakan sangat tidak puas dengan sistem mobile application Garuda Indonesia. Pada mobile application Garuda Indonesia menemukan banyak hal negatif seperti timbul ketidakpuasan pada wisatawan dalam pemakaian mobile application Garuda Indonesia yang dapat dilihat pada data rating dan review wisatawan, maka wisatawan akan beralih menggunakan mobile application yang disediakan oleh pesaing yang kualitasnya jauh lebih baik dan dapat memenuhi harapan wisatawan. Rendahnya rating mobile application Garuda Indonesia tidak sesuai dengan jumlah pembelian tiket pesawat yang meningkat melalui mobile application Garuda Indonesia. Rendahnya rating pada kedua perangkat smartphone (iOs dan Android) membuat mobile application Garuda Indonesia diperlukan pembenahan, sehingga tingkat penjualan tiket pesawat melalui mobile application yang sekarang akan lebih optimal untuk kedepannya nanti. Buchari Alma (2009:59) menegaskan, setelah melakukan penilaian maka diambil keputusan membeli atau tidak membeli.

Proses pembelian oleh wisatawan memiliki beberapa faktor yang dipertimbangkan. Keputusan pembelian menurut Kotler dan Keller (2009) yaitu salah satu tahap dalam proses keputusan pembelian dimana konsumen benar-benar membuat keputusan untuk membeli. Proses keputusan pembelian dibagi menjadi lima tahap, yaitu pengenalan masalah, pencarian informasi, evaluasi alternatif, keputusan pembelian, dan perilaku pascapembelian. Dari pernyataan tersebut dapat diketahui bahwa penting menimbulkan keputusan pembelian konsumen. Oleh sebab itu, penelitian ini mengenai keputusan pembelian yang sangat penting untuk dilakukan karena dengan mengetahui faktor yang mempengaruhi keputusan pembelian maka pihak Garuda Indonesia dapat mencapai harapannya yaitu mendapatkan keputusan pembelian melalui mobile application dari wisatawan. Penelitian ini diharapkan dapat memberikan gambaran mengenai pendapat dari pengguna smartphone terkait harga, kemudahan penggunaan, dan kepercayaan dimana ketiga hal tersebut dapat meningkatkan jumlah pembelian tiket pesawat melalui mobile application Garuda Indonesia, maka perlu adanya penelitian lebih lanjut pengguna maskapai Garuda Indonesia mengenai bagaimana pengaruh harga, kemudahan, dan kepercayaan terhadap keputusan pembelian tiket pesawat oleh wisatawan domestik pada mobile application Garuda Indonesia di DKI Jakarta.

\section{METODE}

Penelitian ini dilakukan di maskapai Garuda Indonesia, dikarenakan Garuda Indonesia merupakan maskapai terbesar di Indonesia selain itu Garuda Indonesia salah satu maskapai yang dimiliki oleh Negara. Variabel pertama yang digunakan untuk mengukur keputusan pembelian tiket pesawat oleh wisatawan domestik melalui mobile application Garuda Indonesia di DKI Jakarta adalah harga berupa keterjangkauan harga, daya saing harga, kesesuaian harga dengan kualitas produk, dan kesesuaian harga dengan manfaat produk. Variabel kedua yang digunakan adalah kemudahan berupa mudah untuk berinteraksi, mudah melakukan transaksi, mudah memperoleh produk, mudah 
untuk dipelajari, dan mudah untuk digunakan. Variabel ketiga yang digunakan adalah kepercayaan berupa kejujuran dalam mengelola situs jual beli online, kompetensi, dan informasi yang diberikan dapat dipercaya. Variabel keempat yang digunakan adalah keputusan pembelian berupa kemantapan terhadap produk, pembelian produk sesuai dengan kebutuhan, merekomendasikan kepada orang lain, dan melakukan pembelian ulang.

Teknik pengumpulan data yang digunakan yaitu observasi, wawancara, penyebaran kuesioner, studi dokumentasi, studi kepustakaan. Penentuan informan dan responden ditentukan secara sengaja dengan menggunakan teknik purposive sampling kepada orang-orang yang dipandang tahu tentang situasi sosial tersebut. Metode yang digunakan dalam pengambilan sampel adalah accidential sampling, siapa saja yang secara kebetulan dapat dijadikan sebagai sampel dan cocok sebagai sumber data (Sugiyono, 2014). Jumlah responden yang digunakan menggunakan rumus Slovin yang sudah terhitung sebanyak 100 responden. Teknik analisis data dalam penelitian ini adalah analisis deskriptif, uji validitas dan reliabilitas, uji asumsi klasik, uji hipotesis, analisis linier berganda, analisis korelasi, dan analisis koefisien determinasi dengan menggunakan SPSS version 21.0 for windows.

\section{HASIL}

\section{Karakteristik Wisatawan}

Dari 100 responden dalam penelitian ini merupakan wisatawan domestik yang telah membeli tiket pesawat melalui mobile application Garuda Indonesia. Karakteristik responden berdasarkan usia menunjukkan bahwa 100 responden yang mengisi kuesioner merupakan wisatawan yang berusia $19 \mathrm{~s} / \mathrm{d} 28$ tahun sebesar $68 \%$. Berdasarkan jenis kelamin jumlah terbanyak berasal dari wisatawan yang berjenis kelamin perempuan sebesar $57 \%$. Berdasarkan status pernikahan paling banyak wisatawan yang berkunjung mempunyai status belum menikah yaitu sebesar $72 \%$. Karakteristik berdasarkan pendidikan terakhir wisatawan yaitu SMA sebesar $41 \%$.

Karakteristik lainnya yang berpengaruh yaitu berdasarkan pekerjaan yaitu pelajar/mahasiswa sebesar 39\%. Karakteristik wisatawan berdasarkan penghasilanan bulanan yaitu Rp. 2.000.000,- s/d Rp. 5.000.000,- sebesar 61\%. Dapat dilihat lagi karakteristik wisatawan berdasarkan sumber informasi mobile application Garuda Indonesia yaitu social media sebanyak 75\%. Dari sebanyak 100 responden paling sering menggunakan mobile application Garuda Indonesia frekuensi penggunaannya pada 2 s/d 3 kali dengan nilai sebesar $43 \%$.

\section{Hasil Analisis Pengujian Instrumen}

Berdasarkan hasil uji validitas dalam penelitian ini dapat dinyatakan bahwa semua indikator yang digunakan telah diuji dan valid karena telah melebihi syarat koefisien korelasi lebih besar dari 0,3. Intrumen tertinggi dalam penelitian yang diuji yaitu sub variabel kemudahan (X2.2) dengan koefisien korelasi sebesar 0,904. Hasil uji reliabilitas masingmasing variabel menghasilkan nilai tersebut lebih besar dari 0,6 sehingga intrumen dinyatakan reliabel.

\section{Uji Asumsi Klasik}

Pada penelitian ini uji asumsi klasik diuji menggunakan uji normalitas, uji multikulinearitas, dan uji heteroskedastistas hasil tersebut dapat disimpulkan sebagai berikut:

1. Hasil uji normalitas dengan metode One Sample Kolmogorov-Smirnov Test dapat diketahui bahwa nilai Sig. atau probabilitas $>0.05$, hasil uji asumsi klasik pada penelitian ini menunjukkan hasil nilai Sig. 0.157. Hal tersebut dapat disimpulkan bahwa nilai Sig. 0.157 > 0.05 maka penelitian ini berdistribusi normal dan penelitian dapat dilanjutkan pada analisis selanjutnya.

2. Hasil uji multikolinearitas dilihat dari nilai tolerance dan Variance Inflation Factor (VIF) yang dihasilkan setelah pengujian dilakukan, berdasarkan hasil perhitungan nilai Tolerance tidak ada variabel independen yang memiliki nilai Tolerance $>0.01$ dengan nilai Tolerance masing-masing variabel independen nilai tolerance bernilai harga sebesar 0.655 , kemudahan sebesar 0.504, dan kepercayaan sebesar 0.496. Sementara itu hasil perhitungan nilai Variance Inflation Factor (VIF) juga menunjukkan hal serupa yaitu tidak adanya nilai VIF dari variabel independen yang memiliki nilai VIF > 10 dengan nilai VIF masingmasing variabel independen bernilai 
Harga sebesar 1.526, Kemudahan sebesar 1.983, dan Kepercayaan sebesar 2.017. Dapat diketahui bahwa ketiga variabel independen mempunyai nilai Tolerance $>$ dari 0,01 dan nilai VIF $<10$. Dalam hal ini hasil perhitungan nilai Tolerance dan VIF dapat disimpulkan bahwa tidak ada multikolinieritas antar variabel independen.

3. Hasil uji heteroskedastisitas menurut Ghozali (2013: 142) salah satu cara untuk mendeteksi ada tidaknya heteroskedastisitas adalah dengan melakukan uji Glejser. Uji Glejser mengusulkan untuk meregres nilai absolut residual terhadap variabel independen. Hasil probabilitas dikatakan signifikan jika nilai signifikansinya diatas tingkat kepercayaan 0.05 hasil yang didapatkan pada penelitian ini memiliki nilai masing-masing variabel sebesar nilai Sig. harga sebesar 0.120 , nilai Sig. variabel kemudahan 0.929, dan nilai Sig. variabel kepercayaan sebesar 0.625 yang artinya tidak terjadi gejala heteroskedastisitas dalam penelitian ini.

\section{Uji t (Parsial)}

Menurut Ghozali, 2016:97 kriteria pengujian dengan tingkat Sig. 0.05 yaitu jika probability $\mathrm{t}<0,05$ maka $\mathrm{Ha}$ diterima, sedangkan jika jika probability $\mathrm{t}>0,05$ maka Ha ditolak. Berdasarkan hasil penelitian dapat dilihat pengaruh dari masing-masing variabel independen terhadap keputusan pembelian tiket pesawat oleh wisatawan domestik melalui mobile application Garuda Indonesia di DKI Jakarta (dependen) sebagai berikut:

1. Pengaruh harga (X1) terhadap keputusan pembelian (Y)

Hasil uji hipotesis 1 yang ditunjukkan pada Tabel 2, harga mempunyai tingkat Sig. sebesar 0.007 dan nilai t sebesar 2.757 hal ini berarti Ho ditolak sehingga dapat dikatakan bahwa harga memiliki pengaruh signifikan terhadap keputusan pembelian. Karena tingkat signifikan yang dimiliki variabel tersebut $<0.05(0.007<0.05)$ dengan koefisien yang bertanda positif. Berdasarkan $\mathrm{H} 1$ yang terdapat pada bagian pengembangan hipotesis yang sesuai dengan hasil pengujian parsial yang telah dilakukan oleh peneliti sehingga dapat disimpulkan untuk variabel harga (X1) menunjukkan Ho ditolak yang berarti secara parsial variabel harga berpengaruh singnifikan terhadap keputusan pembelian tiket pesawat oleh wisatawan domestik melalui mobile application Garuda Indonesia di DKI Jakarta.

2. Pengaruh kemudahan (X2) terhadap keputusan pembelian (Y)

Hasil uji hipotesis 2 yang ditunjukkan pada Tabel 2, kemudahan mempunyai tingkat Sig. sebesar 0.001 dan nilai $t$ sebesar 3.533 hal ini berarti Ho ditolak sehingga dapat dikatakan bahwa harga memiliki pengaruh signifikan terhadap keputusan pembelian. Karena tingkat signifikan yang dimiliki variabel tersebut $<0.05(0.001<0.05)$ dengan koefisien yang bertanda positif. Berdasarkan H2 yang terdapat pada bagian pengembangan hipotesis yang sesuai dengan hasil pengujian parsial yang telah dilakukan oleh peneliti sehingga dapat disimpulkan untuk variabel kemudahan (X2) menunjukkan Ho ditolak yang berarti secara parsial variabel kemudahan berpengaruh singnifikan terhadap keputusan pembelian tiket pesawat oleh wisatawan domestik melalui mobile application Garuda Indonesia di DKI Jakarta.

3. Pengaruh kepercayaan (X3) terhadap keputusan pembelian (Y)

Hasil uji hipotesis 3 yang ditunjukkan pada Tabel 2, kepercayaan mempunyai tingkat Sig. sebesar 0.000 dan nilai $\mathrm{t}$ sebesar 3.958 hal ini berarti Ho ditolak sehingga dapat dikatakan bahwa harga memiliki pengaruh signifikan terhadap keputusan pembelian. Karena tingkat signifikan yang dimiliki variabel tersebut $<0.05(0.000<0.05)$ dengan koefisien yang bertanda positif. Berdasarkan $\mathrm{H} 3$ yang terdapat pada bagian pengembangan hipotesis yang sesuai dengan hasil pengujian parsial yang telah dilakukan oleh peneliti sehingga dapat disimpulkan untuk variabel kepercayaan (X3) menunjukkan Ho ditolak yang berarti secara parsial variabel kepercayaan berpengaruh singnifikan terhadap keputusan pembelian tiket pesawat oleh wisatawan domestik melalui mobile application Garuda Indonesia di DKI Jakarta. 


\section{Uji F (Simultan)}

Menurut Ghozali (2005) uji F pada dasarnya menunjukkan apakah semua variabel independen atau bebas yang dimasukkan dalam model mempunyai pengaruh secara bersama terhadap variabel dependen atau terikat. Probabilitas lebih kecil dari 0,05 maka hasilnya signifikan berarti terdapat pengaruh dari variabel independen secara bersama terhadap variabel dependen. Berdasarkan hasil penelitian menunjukan bahwa nilai Sig. untuk pengaruh variable $\mathrm{X}$ secara simultan berpengaruh terhadap $\mathrm{Y}$ adalah sebesar 0,000 yang berarti Sig. Uji F $0.000<$ kriteria signifikan $5 \%$ atau $(0,05)$. Sedangkan nilai $F_{\text {hitung }} 48.204$ dan nilai $F_{\text {tabel }} 2.70$, yang artinya nilai $F_{\text {hitung }} 48.204>$ nilai $F_{\text {tabel }} 2.70$ dengan demikian dapat menunjukkan bahwa secara bersama-sama (simultan) variabel harga (X1), kemudahan (X2), dan kepercayaan (X3) berpengaruh signifikan terhadap variabel dependen keputusan pembelian (Y) tiket pesawat oleh wisatawan domestik melalui mobile application Garuda Indonesia di DKI Jakarta.

\section{Analisis Regresi Berganda}

Menurut Ghozali (2005) analisis regresi berganda adalah hubungan secara linear antara dua atau lebih variabel independen $(\mathrm{X})$ dengan variabel dependen (Y). Analisis regresi berganda digunakan untuk menganalisis pengaruh variabel bebas yang terdiri dari harga (X1), kemudahan (X2), dan kepercayaan (X3) terhadap variabel terikat yaitu keputusan pembelian (Y) tiket pesawat oleh wisatawan domestik melalui mobile application Garuda Indonesia di DKI Jakarta. Berdasarkan hasil penelitian maka dapat diketahui persamaan regresi sebagai berikut:

$$
\begin{aligned}
\mathrm{Y}= & 1.137+0.221(\mathrm{X} 1)+0.266(\mathrm{X} 2)+0.509 \\
& (\mathrm{X} 3)+\mathrm{e}
\end{aligned}
$$

Hasil persamaan analisis regresi linier berganda dapat diketahui sebagai berikut:

1. Jika seluruh variabel bebas dinyatakan konstan pada angka nol (0), maka keputusan pembelian tiket pesawat oleh wisatawan domestik melalui mobile application Garuda Indonesia di DKI Jakarta sebesar 1.137.
2. Nilai koefisien regresi harga (X1) sebesar 0.221 menunjukkan bahwa variabel harga mempunyai hubungan positif terhadap keputusan pembelian tiket pesawat oleh wisatawan domestik melalui mobile application Garuda Indonesia di DKI Jakarta yang berarti semakin meningkat harga maka keputusan pembelian tiket pesawat oleh wisatawan domestik melalui mobile application Garuda Indonesia di DKI Jakarta tersebut akan meningkat sebesar 0.221.

3. Nilai koefisien regresi kemudahan (X2) sebesar 0.266 menunjukkan bahwa variabel kemudahan mempunyai hubungan positif terhadap keputusan pembelian tiket pesawat oleh wisatawan domestik melalui mobile application Garuda Indonesia di DKI Jakarta yang berarti semakin meningkat kemudahan maka keputusan pembelian tiket pesawat oleh wisatawan domestik melalui mobile application Garuda Indonesia di DKI Jakarta tersebut akan meningkat sebesar 0.266 .

4. Nilai koefisien regresi kepercayaan (X3) sebesar 0.509 menunjukkan bahwa variabel kepercayaan mempunyai hubungan positif terhadap keputusan pembelian tiket pesawat oleh wisatawan domestik melalui mobile application Garuda Indonesia di DKI Jakarta yang berarti semakin meningkat kepercayaan maka keputusan pembelian tiket pesawat oleh wisatawan domestik melalui mobile application Garuda Indonesia di DKI Jakarta tersebut akan meningkat sebesar 0.509 .

\section{Analisis Korelasi}

Menurut Supranto (1989:36), untuk mengetahui kuat lemahnya tingkat derajat hubungan koefisien korelasi. Berdasarkan hasil penelitian menunjukkan bahwa besarnya koefision korelasi yaitu $(\mathrm{R}=0.778)$, yang dimana berarti variabel bebas (harga, kemudahan, dan kepercayaan) mempunyai hubungan yang kuat dengan variabel dependen (keputusan pembelian).

\section{Analisis Koefisien Determinasi}

Dalam output SPSS, koefisien determinasi terletak pada tabel model summary dan tertulis $\mathrm{R}$ square yang sudah disesuaikan 
atau tertulis adjust $\mathrm{R}$ square, karena disesuaikan dengan jumlah variabel independen (Ghozali, 2005). Berdasarkan hasil penelitian, hasil analisis uji koefisien determinas $\left(R^{2}\right)$ pada penelitian ini menunjukkan bahwa variable harga, kemudahan, dan kepercayaan berpengaruh terhadap variable keputusan pembelian sebesar $60.6 \%$ sementara sisanya yaitu $100 \%-60,6 \%$ $=39.4 \%$ dipengaruhi oleh faktor-faktor lain yang didalamnya mempengaruhi wisatawan domestik terhadap keputusan pembelian tiket pesawat melalui mobile application Garuda Indonesia di DKI Jakarta.

\section{Pengaruh Harga terhadap Keputusan Pembelian}

Hipotesis pertama menunjukkan bahwa harga berpengaruh positif dan signifikan terhadap keputusan pembelian. Berdasarkan nilai $t_{\text {hitung }}$ sebesar 2.757 yang dihasilkan pada variabel harga lebih besar dari nilai $t_{\text {tabel }}$ sebesar 1.98552. Dengan demikian hasil pengujian hipotesis menunjukkan arah positif yang berarti bahwa nilai Sig. 0.007 yang dimana $<0.05$, maka dengan hal tersebut variabel harga dinyatakan mempengaruhi variabel keputusan pembelian.

Pengukuran variabel harga yang dimaksud dalam penelitian ini terdapat beberapa indikator diantaranya yaitu wisatawan domestik merasa harga tiket pesawat di sistem mobile application Garuda Indonesia lebih terjangkau dibandingkan dengan harga yang dijual oleh e-commerce lainnya, wisatawan domestik merasa harga tiket pesawat di sistem mobile application Garuda Indonesia dapat bersaing dengan harga tiket pesawat yang lain dimana seperti yang dijelaskan dalam kalimat sebelumnya, wisatawan domestik merasa harga tiket pesawat di sistem mobile application Garuda Indonesia sesuai dengan kualitas produk/jasa yang ditawarkan, dan harga tiket pesawat di sistem mobile application Garuda Indonesia sesuai dengan manfaat yang dirasakan oleh wisatawan domestik.

Berdasarkan hasil dari pengukuran variabel harga terhadap variabel keputusan pembelian dengan menggunakan 100 responden maka diketahui di sisi lain dari variabel harga tersebut terdapat 1 indikator yang menunjukkan nilai yang rendah diantara 4 indikator dalam penelitian ini, dimana indikator tersebut adalah harga tiket pesawat di sistem mobile application Garuda Indonesia terjangkau memiliki nilai rata-rata sebesar 3.57 dalam kategori setuju. Hal ini dikarenakan Garuda Indonesia bukan termasuk low cost carrer hal tersebut dikarenakan harga tiket pesawat yang terjangkau dari Garuda Indonesia untuk wisatawan yang memiliki ekonomi menengah keatas dan dengan harga yang diberikan Garuda Indonesia sesuai dengan kualitas pelayanan yang diterima oleh wisatawan pengguna mobile application Garuda Indonesia. Hal tersebut diperkuat oleh hasil komentar dan saran dalam hasil kuisioner yang peneliti lakukan, pada tanggal 13 September 2018 dengan wisatawan yang bernama Jelita berikut kutipan komentar dan sarannya "aplikasi garuda indonesia sangat membantu untuk konsumen agar dapat dengan mudah membeli tiket pesawat yang terjangkau.". Oleh karena itu semakin variatif harga tiket pesawat Garuda Indonesia maka keputusan pembelian secara online akan mengalami peningkatan dalam penjualan tiket pesawat melalui mobile application Garuda Indonesia.

\section{Pengaruh Kemudahan terhadap Keputusan Pembelian}

Hipotesis kedua menunjukkan bahwa kemudahan berpengaruh positif dan signifikan terhadap keputusan pembelian. Berdasarkan nilai $t_{\text {hitung }}$ sebesar 3.533 yang dihasilkan pada variabel kemudahan lebih besar dari nilai $t_{\text {tabel }}$ sebesar 1.98552. Dengan demilikian hasil pengujian hipotesis menunjukkan arah positif yang berarti bahwa nilai Sig. 0.001 yang dimana $<0.05$, maka dengan hal tersebut variabel kemudahan dinyatakan mempengaruhi variabel keputusan pembelian.

Pengukuran variabel kemudahan yang dimaksud dalam penelitian ini terdiri dari beberapa indikator diantaranya yaitu wisatawan domestik mudah berinteraksi dalam menggunakan sistem mobile application Garuda Indonesia, wisatawan domestik merasa mudah bertransaksi dengan menggunakan sistem mobile application Garuda Indonesia dalam pemesanan tiket pesawat karena wisatawan dapat melakukannya dimanapun dan kapanpun dengan syarat terdapat koneksi internet, sistem mobile application Garuda Indonesia memberikan wisatawan domestik kemudahan dalam mendapatkan tiket pesawat 
karena mobile application Garuda Indonesia dirancang lebih mudah dan lengkap dalam penggunaannya, sistem mobile application Garuda Indonesia memudahkan wisatawan domestik untuk dipahami pengoperasiannya, dan sistem mobile application Garuda Indonesia yang diberikan mudah untuk digunakan oleh wisatawan domestik.

Berdasarkan hasil dari pengukuran variabel kemudahan terhadap variabel keputusan pembelian dengan menggunakan 100 responden maka diketahui di sisi lain dari variabel kemudahan tersebut terdapat 1 indikator yang menunjukkan nilai yang rendah diantara 4 indikator dalam penelitian ini, dimana indikator tersebut adalah wisatawan mudah untuk berinteraksi pada mobile application Garuda Indonesia memiliki nilai rata-rata sebesar 4.02 dalam kategori setuju. Hal ini dikarenakan wisatawan sering terkendala ketika mereka melakukan perjalanan ke suatu daerah yang memiliki koneksi internet buruk akan mengganggu dalam pemesanan tiket pada mobile application Garuda Indonesia. Sehingga diharapkan Garuda Indonesia dapat mengupayakan pembenahan sistem yang ada supaya wisatawan domestik tidak merasa kesulitan untuk mengikuti proses transaksi yang harus dijalani.

Hal ini diperkuat dengan hasil komentar dan saran dalam kuisioner yang peneliti lakukan, pada tanggal 18 September 2018 dengan wisatawan yang bernama Bambang Hartono berikut kutipan komentar dan sarannya "lebih ditingkatkan lagi bentuk sistem mobile applictation Garuda Indonesia serta user interface, user experience, dan user friendly agar lebih memudahkan penggunaan aplikasi Garuda Indonesia dalam semua kalangan usia.". Berdasarkan kutipan komentar dan saran tersebut, kutipan review user interface di mobile application Garuda Indonesia menurut Belia Satyanegara melalui Android version pada tanggal 27 Mei 2015 mengatakan "UI keren...menu2 juga cukup simpel", dimana dalam teori user interface merupakan penciptaan sebuah media komunikasi yang efektif antara manusia dengan sistem (Pressman, 2010), sedangkan dalam kenyataannya user interface dapat dilihat dari tampilan mobile application Garuda Indonesia yang menarik.
Kutipan review user experience di mobile application Garuda Indonesia menurut Fitriyah Taufik melalui Android version pada tanggal 5 Juni 2017 mengatakan "kenapa orang lain banyak yang complain ya? Sy malah lebih suka versi yang terbaru ini dibanding yang lama, walau loading sy akui agak lebih lambat. Tapi semua fungsi berjalan dengan baik, termasuk check in mobile Dan my trip", dimana dalam teori user experience merupakan persepsi seseorang dan responnya dari penggunaan sebuah produk, sistem, atau jasa (ISO 9241-210), dari persepsi tersebut terdapat pesan bahwa pengguna mobile aplikasi Garuda Indonesia mampu mengutarakan pengalamannya dalam menggunakan mobile application yang masih tergolong baru kemudian persepsinya tersebut mampu mengubah cara pandang calon atau pengguna lainnya khususnya wisatawan yang sering membeli tiket pesawat melalui mobile aplikasi Garuda Indonesia. Kemudian kutipan review user experience di mobile application Garuda Indonesia menurut Soybean Tofu melalui $i O s$ version mengatakan "Saya sering mengalami crash \& error pada aplikasi, cara untuk mengatur kembali adalah dengan menghapus \& meng-install aplikasinya kembali". Sedangkan pengalaman pengguna mobile application Garuda Indonesia lainnya dari versi yang lama sampai yang terbaru telah membuat mobile application Garuda Indonesia terus mendapat sorotan dari waktu ke waktu karena pembaharuan yang selalu dilakukan oleh pihak Garuda Indonesia.

Setelah itu kutipan review user friendly di mobile application Garuda Indonesia menurut BeeandMee melalui iOs version mengatakan "Terimakasih garuda! Membuat hidup saya lbh gampang kalau mau booking tiket. Friendly app", dimana user friendly dapat membuat seseorang pemula tidak kesulitan dalam mengoperasikan perangkat lunak dan program aplikasi, maka sistem pada mobile application Garuda Indonesia harus dipertahankan kemudahannya bahkan lebih ditingkatkan karena akan lebih mudah berinteraksi dalam sistem mobile application Garuda Indonesia, contohnya adalah petunjuk penggunaan yang terdapat ketika memulai mobile application Garuda Indonesia bagi pengguna pemula. Semakin meningkatnya kemudahan dalam menggunakan e-commerce maka keputusan pembelian secara online juga 
akan mengalami peningkatan dan berbagai macam pertimbangan yang memudahkan pengguna akan membuat persepsi yang baik, pengalaman yang menarik, serta memudahkan bagi pengguna.

\section{Pengaruh Kepercayaan terhadap Keputusan Pembelian}

Hipotesis ketiga menunjukkan bahwa kepercayaan berpengaruh positif dan signifikan terhadap keputusan pembelian. Berdasarkan nilai $t_{\text {hitung }}$ sebesar 3.958 yang dihasilkan pada variabel kepercayaan lebih besar dari nilai $t_{\text {tabel }}$ sebesar 1.98552. Dengan demilikian hasil pengujian hipotesis menunjukkan arah positif yang berarti bahwa nilai Sig. 0.000 yang dimana $<0.05$, maka dengan hal tersebut variabel kepercayaan dinyatakan mempengaruhi variabel keputusan pembelian.

Pengukuran variabel kepercayaan yang dimaksud dalam penelitian ini terdapat beberapa indikator diantaranya yaitu transaksi yang dilakukan oleh wisatawan domestik melalui sistem mobile application Garuda Indonesia yang jelas dan detail dikarenakan sistem mobile application Garuda Indonesia memberikan informasi yang jelas terkait metode pembayaran yang akan digunakan oleh pengguna aplikasinya, wisatawan domestik merasa sistem mobile application Garuda Indonesia dapat bersaing dengan sistem mobile application maskapai lainnya dikarenakan sistem mobile application Garuda Indonesia lebih memiliki nama atau citra yang baik dimata wisatawan sebab Garuda Indonesia merupakan maskapai terbaik dan terbesar di Indonesia, dan informasi yang diberikan oleh sistem mobile application Garuda Indonesia mengenai jenis produk jasa, cara pembayaran, dapat dipercayai oleh wisatawan domestik.

Berdasarkan hasil dari pengukuran variabel kepercayaan terhadap variabel keputusan pembelian dengan menggunakan 100 responden maka diketahui di sisi lain dari variabel kepercayaan tersebut terdapat 1 indikator yang menunjukkan nilai yang rendah diantara 3 indikator dalam penelitian ini, dimana indikator tersebut adalah transaksi yang dilakukan oleh wisatawan domestik melalui sistem mobile application Garuda Indonesia akurat dan transparan memiliki nilai rata-rata sebesar 4.13 dalam kategori setuju. Hal ini dikarenakan transaksi yang ada pada mobile application Garuda Indonesia sangat jelas terkait metode pembayaran dan informasi jumlah pembayaran serta detail transaksi yang dikirim melalui e-mail berupa invoice pembelian.

Hal ini diperkuat dari hasil komentar dan saran dalam hasil kuisioner yang peneliti lakukan, pada tanggal 05 September 2018 dengan wisatawan yang bernama Dian berikut kutipan komentar dan sarannya "sejauh ini memudahkan konsumen untuk melakukan transaksi pada sistem mobile application Garuda Indonesia.", pada tanggal 06 September 2018 dengan wisatawan yang bernama Meisya berikut kutipan komentar dan sarannya "beberapa fitur baru pada aplikasi ini dirasa sangat membantu dan memberikan informasi secara spesifik.", dan pada tanggal 06 September 2018 dengan wisatawan yang bernama Hanifah berikut kutipan komentar dan sarannya "semoga mobile application ini dapat dikenal semua kalangan, sehingga lebih praktis dan lebih mudah.". Dalam hal tersebut unsur kepercayaan yang diberikan dengan tujuan memberikan kepercayaan terhadap wisatawan yang mengutamakan dan memperhatikan wisatawan terlaksana dengan maksimal. Oleh karena itu kepercayaan harus diperbaiki dan dijalankan semaksimal mungkin karena nantinya akan mempengaruhi keputusan pembelian dan dengan demikian para wisatawan akan semakin antusias dan dapat merekomendasikan untuk membeli tiket pesawat melalui mobile application Garuda Indonesia. Penelitian ini sejalan dengan hasil penelitian Negara dan Sagita (2018) bahwa kepercayaan wisatawan akan informasi yang tersedia secara online juga menjadi faktor pendorong wisatawan untuk mempercayakan alat ini sebagai online guide yang menuntun dimana mereka akan berwisata. Kecanggihan smartphone dapat membantu menuntaskan kejadian tidak terduga ini, karena informasi dapat diakses wisatawan saat dalam perjalanan wisata.

Pengaruh Harga, Kemudahan, dan
Kepercayaan Secara Simultan terhadap
Keputusan Pembelian
Secara simultan tiga variabel indipenden terbukti berpengaruh terhadap dependen, karena nilai Sig. sebesar 0,000 yang berarti nilai tersebut lebih kecil dari kriteria nilai Sig. $(0,05)$. Sedangkan nilai $F_{\text {hitung }} 48.204$ dan 
nilai $F_{\text {tabel }} 2.70$, yang artinya nilai $F_{\text {hitung }}$ lebih besar dari nilai $F_{\text {tabel }}$, dengan demikian dapat menunjukkan bahwa secara bersamasama (simultan) variabel harga (X1), kemudahan (X2), dan kepercayaan (X3) berpengaruh signifikan terhadap variabel dependen keputusan pembelian (Y) tiket pesawat oleh wisatawan domestik melalui mobile application Garuda Indonesia di DKI Jakarta.

Pada penelitian ini terdapat tiga variabel wisatawan melakukan keputusan pembelian melalui mobile application Garuda Indonesia yaitu harga, kemudahan, dan kepercayaan. Pengaruh harga pada suatu produk atau jasa juga sangat penting, hal tersebut dikarenakan jika harga rendah maka permintaan produk atau jasa yang ditawarkan semakin meningkat dan jika harga produk atau jasa semakin tinggi maka permintaan produk atau jasa semakin rendah, hal ini sesuai dengan hukum permintaan menurut Sugiarto (2002). Penetapan harga yang tepat akan mendapatkan perhatian besar dari wisatawan domestik maupun wisatawan mancanegara, jika harga yang ditetapkan oleh perusahaan tepat dan sesuai dengan daya beli konsumen maka pemilihan suatu produk atau jasa akan dijatuhkan pada produk atau jasa tersebut. Perusahaan menetapkan harga karena disesuaikan dengan kualitas produk atau jasa yang ada. Setelah harga, perusahaan menciptakan kemudahan terhadap sistem mobile application tersebut. Perusahaan biasanya memberikan kemudahan dalam menggunakan suatu sistem mobile application dengan cara memberikan informasi petunjuk ataupun informasi lainnya di dalam sistem mobile application tersebut. Kemudahan yang dimaksud adalah kemudahan untuk berinteraksi, bertransaksi, memperoleh produk, mudah untuk dipelajari, dan mudah untuk digunakan karena mobile application Garuda Indonesia dibuat oleh perusahaan Garuda Indonesia dengan fitur yang lengkap dan kejelasan informasi tiket penerbangan. Setelah wisatawan merasakan kemudahan dalam menggunakan sistem mobile application tersebut, wisatawan akan mendapatkan kepercayaan untuk mengambil keputusan pembelian melalui sistem mobile application tersebut. Kepercayaan wisatawan merupakan salah satu faktor yang menjadi suatu pertimbangan dalam mengambil keputusan pembelian. Perusahaan harus mampu menciptakan kepercayaan wisatawan terhadap produk ataupun jasa yang ditawarkan karena hal ini bertujuan untuk menarik perhatian serta menimbulkan minat dan keyakinan wisatawan terhadap produk ataupun jasa yang dipasarkan tersebut. Jadi dapat disimpulkan bahwa harga, kemudahan dan kepercayaan yang diberikan oleh Garuda Indonesia mampu mempengaruhi wisatawan untuk membeli tiket pesawat Garuda Indonesia.

\section{SIMPULAN DAN SARAN Simpulan}

Variabel harga (X1) memiliki nilai $t_{\text {hitung }}$ sebesar $2.757>$ nilai $t_{\text {tabel }}$ sebesar 1.98552, maka hipotesis pertama diterima karena terdapat pengaruh signifikan antara harga (X1) terhadap keputusan pembelian (Y) tiket pesawat oleh wisatawan domestik melalui mobile application Garuda Indonesia di DKI Jakarta.

Variabel kemudahan (X2) memiliki nilai $t_{\text {hitung }}$ sebesar $3.533>$ nilai $t_{\text {tabel }}$ sebesar 1.98552, maka hipotesis pertama diterima karena terdapat pengaruh signifikan antara kemudahan (X2) terhadap keputusan pembelian (Y) tiket pesawat oleh wisatawan domestik melalui mobile application Garuda Indonesia di DKI Jakarta.

Variabel kepercayaan (X3) memiliki nilai $t_{\text {hitung }}$ sebesar 3.958 yang dimana $>$ nilai $t_{\text {tabel }}$ sebesar 1.98552, maka hipotesis pertama diterima karena terdapat pengaruh signifikan antara kepercayaan (X3) terhadap keputusan pembelian (Y) tiket pesawat oleh wisatawan domestik melalui mobile application Garuda Indonesia di DKI Jakarta.

Variabel harga (X1), kemudahan (X2), dan kepercayaan (X3) memiliki nilai $F_{\text {hitung }}$ $48.204>$ nilai $F_{\text {tabel }} 2.70$, Dari nilai tersebut menunjukkan bahwa pengaruh secara bersama-sama (simultan) variabel harga (X1), kemudahan (X2), dan kepercayaan (X3) berpengaruh signifikan terhadap variabel dependen keputusan pembelian (Y) tiket pesawat oleh wisatawan domestik melalui mobile application Garuda Indonesia di DKI Jakarta.

\section{Saran}

Untuk Developer Mobile Application Garuda Indonesia harus lebih diperbaiki lagi 
terhadap sistem penggunaan, agar memudahkan wisatawan yang akan menggunakan mobile application Garuda Indonesia dari tampilan, petunjuk, penggunaan dapat ditingkatkan lagi. Untuk pihak perusahaan Garuda Indonesia agar lebih memperhatikan penjualan melalui mobile application Garuda Indonesia agar pengguna yang akan menggunakan mobile application Garuda Indonesia lebih banyak daripada sebelumnya, karena mobile application Garuda Indonesia lebih baik dibandingkan website Garuda Indonesia.

Bagi peneliti selanjutnya diharapkan agar menambah variabel lain yang tidak disertakan pada penelitian ini, sehingga nantinya memperoleh hasil penelitian yang lebih menyeluruh terkait dengan keputusan pembelian tiket pesawat oleh wisatawan domestik melalui mobile application Garuda Indonesia. Untuk peneliti selanjutnya agar mempertimbangkan jumlah sampel yang dapat mewakili populasi pengguna mobile application Garuda Indonesia dan variabel tambahan seperti variabel dalam konsep pemasaran selain harga, dalam konsep TAM seperti manfaat penggunaan, dan variabel psikologis kecuali kepercayaan.

Berdasarkan hasil observasi sebelum melakukan penelitian ini, peneliti melihat rating ataupun review mobile application Garuda Indonesia di PlayStore dan App Store didapatkan hasil bahwa kebanyakan wisatawan mengeluhkan kemudahan dalam mengakses sistem mobile application Garuda Indonesia, salah satu keluhannya merupakan sering terjadi crash atau error jika membuka mobile application Garuda Indonesia. Maka dari itu peneliti menyarankan kepada pihak Garuda Indonesia harus meningkatkan lagi dengan memperbaiki sistem mobile application supaya sistem tersebut tidak terjadi crash ataupun error apabila diakses oleh banyak wisatawan. Hal ini dikarenakan kemudahan merupakan salah satu faktor terpenting yang mempengaruhi keputusan pembelian tiket pesawat oleh wisatawan domestik melalui mobile application Garuda Indonesia di DKI Jakarta. 


\section{Kepustakaan}

Ani. 2009. Pengguna Internet Indonesia tumbuh 1000 persen. Kompas Cyber Space. Diakses dari http://www.kompas.com pada tanggal 20 Juli 2018, 13:30 WITA.

Buchari, A, 2009. Manajemen Pemasaran dan Pemasaran Jasa. Bandung : CV Alvabeta.

Ghozali, Imam. 2005. Aplikasi Analisis Multivariate dengan program SPSS, Badan Penerbit Universitas Diponegoro, Semarang.

2016. Aplikasi Analisis Multivariate dengan Program SPSS Edisi 8 . Badan penerbit UNDIP.

Herlina, O. 2013. Komunikasi Pemasaran Pariwisata DIY melalui Pemanfaatan ETourism oleh Swasta dan Pemerintah (Studi Komparatif www.visitingjogja.com dan www.Yogyes.com). Tesis. Universitas Gadjah Mada: Yogyakarta.

Hidayat, I., Arifin, R., dan Priyono, A. A. (2017). Pengaruh Kepercayaan, Kemudahan, Harga, Dan Kulitas Informasi Pengguna E-Commerce Terhadap Keputusan Pembelian Secara Online Pada Situs Bukalapak.com (Studi Pada Mahasiswa S1 Fak. Ekonomi Unisma Angkatan 2013). Universitas Islam Malang.

Hyde, K.F. 2008. Information Processing and Touring Planning Theory. Annals of Tourism Research. Vol.35, Issue 3, p: 712-713.

Kotler, Philip dan Kevin Lane, Keller. 2009. Manajemen Pemasaran. Jilid 1 dan 2. Edisi 13. Jakarta: Erlangga.

Mahkota, A.P., Suyadi, I., dan Riyadi. 2014. Pengaruh Kepercayaan Dan Kenyamanan Terhadap Keputusan Pembelian Online (Studi Pada Pelanggan Website Ride Inc). Jurnal Administrasi Bisnis (JAB). Vol. 8, No. 2, h. 1-7.
Nazarudin, H., dan Pela, Y. 2016. Pengaruh Kemudahan Dan Kualitas Informasi Terhadap Keputusan Pembelian Secara Online Di Situs D'BC Network Orifline (Studi Pada Masyarakat Fatufeto Kota Kupang). Jurnal Bisnis \& Manajemen. Vol. 2 No. 2, h. 112-134.

Negara, I. M. K., \& Sagita, P. A. W. (2018). Kapabilitas Praktis Domain Perjalanan Wisata Bali: Aplikasi Perjalanan Wisata Berbasis Ponsel Cerdas. Jurnal IPTA, 6(1), 77-83.

Rosmayana, W. 2017. Pengaruh Kepercayaan, Kemudahan, Kualitas Informasi Dan Persepsi Risiko Terhadap Keputusan Pembelian Online Pengguna Situs Lazada Di Kota Padang). Tugas Akhir. Politeknik Negeri Padang: Padang.

Saputri, A.F.B.A. 2015. Pengaruh Keamanan, Kemudahan, Dan Risiko Kinerja Terhadap Keputusan Pembelian Secara Online Di Tokopedia.Com (Studi Pada Pengguna Situs Belanja Online Tokopedia.Com). Skripsi. Universitas Negeri Yogyakarta: D.I Yogyakarta.

Sugiyono. 2014. Metode Penelitian Kuantitatif, Kualitatif Dan R\&D. Bandung: Alfabeta.

Supranto, J. 1989. Statistik: Teori dan Aplikasi. Edisi Kelima.Jld. 2. Jakarta : Penerbit Erlangga.

Weenas, J. R. (2013). "Kualitas Produk, Harga, Promosi Dan Kualitas Pelayanan Pengaruhnya Terhadap Keputusan Pembelian Spring Bed Comforta." Jurnal Emba: Jurnal Riset Ekonomi, Manajemen, Bisnis Dan Akuntansi, Vol. 1, No. 4, h: 607. 